\title{
ANALISIS RASIO KEUANGAN PADA PT. BAKRIE SUMATERA PLANTATIONS, Tbk. DAN PT. ASTRA AGRO LESTARI, Tbk. PERIODE 2014-2016
}

\author{
Mahagiyani ${ }^{1}$ \\ Hera Ratna Sari ${ }^{2}$ \\ Program Studi Akuntansi, Politeknik LPP Yogyakarta \\ 1) E-mail: yanik gion@yahoo.co.id
}

\begin{abstract}
Abstrak
Kinerja keuangan merupakan gambaran prestasi yang mencakup aspek keuangan, pemasaran, menghimpun dan penyaluran dana serta sumber daya manusia dan lainnya dalam satu periode. Rasio keuangan merupakan alat analisis keuangan perusahaan untuk menilai kinerja suatu perusahaan berdasarkan perbandingan data keuangan yang terdapat pada pos laporan keuangan. Melalui analisis rasio keuangan, perusahaan dapat mengetahui tingkat kesehatan keuangan perusahaan, permasalahan yang sedang dihadapi serta penyebabnya. Ada beberapa jenis rasio keuangan yang sering dipakai dalam menganalisis keuangan perusahaan seperti: Rasio Likuiditas, Rasio Manajemen Aktiva, Rasio Manajemen Utang dan Rasio Profitabilitas. Penelitian ini menggunakan analisis deskriftif, yaitu suatu analisis yang berupaya mendeskripsikan secara sistematis, faktual dan aktual mengenai fakta untuk menarik kesimpulan yang logis mengenai data-data hasil penelitian yang akan dianalisis, yaitu analisis rasio-rasio keuangan. Rasio Lancar PT. Astra Agro Lestari,Tbk.mengalami peningkatan, pada tahun 2014 adalah 0.58 kali. Pada tahun 2015 mengalami kenaikan 0.80 kali. Pada tahun 2016 kembali naik 1.03 kali. Ini berarti, bahwa setiap tahunnya jumlah persediaan men ingkat dan penjualan juga meningkat yang menyebabkan rasio lancar setiap tahun mengalami peningkatan, sehingga perusahaan lebih mampu membayar atau melunasi kewajiban keuangan jangka pendeknya. Jadi jika dinilai dari Likuiditasnya kinerja keuangan PT. Astra Agro Lestari,Tbk periode 2014-2016 da lam kondisi baik. Rasio Utang pada tahun 2014 adalah 36\% pada tahun 2015 meningkat 46\% dan pada tahun 2016 menurun 27\%. Jika dinilai dari Manajemen Utangnya kinerja keuangan PT. Astra Agro Lestari, Tbk. baik karena kurang dari 50\% Aktiva yang dimiliki perusahaan bersumber dari hutang.
\end{abstract}

Kata Kunci : Kinerja Keuangan, Rasio Lancar, Rasio Perputaran Total Aktiva, Rasio Utang, Rasio Pengembalian ata Total Aktiva 


\section{Pendahuluan}

Tujuan dasar dapat tercapai tentunya banyak hal yang mendasari,salah satunya adalah dari aspek keuangan. Beberapa sumber informasi yang dapat digunakan untuk mengetahui tercapai tidaknya tujuan dari sebuah perusahaan adalah melalui laporan keuangannya, yang dilaporkan pada setiap periode. Hasil analisis laporan keuangan dapat menampilkan indikator-indikator penting yang dapat digunakan untuk alat pertimbangan dalam pengambilan keputusan dan memberikan gambaran kinerja dari sebuah perusahaan.

Manajer perusahaan perlu melakukan penilaian terhadap kinerja keuangan untuk mengetahui apakah telah sesuai dengan perencaanan. Cara yang dapat dilakukan untuk menilai kinerja perusahaan adalah dengan melakukan analisis rasio keuangan.

Banyak perusahaan menilai kinerja perusahaannya hanya berdasarkan pada tingkat laba yang diperoleh dan mereka menganggap bahwa kin erja perusahaannya baik jika laba yang diperoleh meningkat setiap tahun, akan tetapi hal ini tidak sepenuhnya benar karena di dalam kenyataannya ada perusahaan yang setiap tahun laba perusahaan meningkat, tetapi perusahaan tersebut mengalami kesulitan keuangan di dalam mengembangkan usaha dan melunasi utang perusahaan. Karena itu laporan keuangan menjadi faktor penting untuk menilai kinerja keuangan, selain itu analisis laporan keuangan juga mampu mengungkapkan permasalahan operasional yang terjadi di dalam perusahaan sehingga dapat dicarikan jalan keluar yang akhirnya dapat mendukung pengambilan keputusan bagi pihak manajemen.

Rasio keuangan merupakan alat analisis keuangan perusahaan untuk menilai kinerja suatu perusahaan berdasarkan perbandingan data keuangan yang terdapat pada pos laporan keuangan. Melalui analis is rasio keuangan, perusahaan dapat mengetahui tingkat kesehatan keuangan perusahaan, permasalahan yang sedang dihadapi serta penyebabnya. Ada beberapa jenis rasio keuangan yang sering dipakai dalam menganalisis keuangan perusahaan seperti: Rasio Likuiditas, Rasio Manajemen Aktiva, Rasio
Manajemen Utang dan Rasio Profitabilitas.

\section{Tujuan dan Manfaat Penelitian}

menguji analisis rasio keuangan dalam menilai kinerja keuangan PT. Bakrie Sumatera Plantations, Tbk. dan PT. Astra Agro Lestari, Tbk. Periode 2014-2016.

\section{Metodologi Penelitian}

Metode penelitian pada penyusunan tugas akhir ini menggunakan metode pendekatan deskriptif kuatitatif yang berupa :

data yang diambil dari PT Bakrie Sumatera Plantations, Tbk. dan PT. Astra Agro Lestari, Tbk. yang berupa laporan keuangan perusahaan periode 2014-2016 di analisis menggunakan suatu teknik yang disebut analisis rasio keuangan, dan hasil analis is tersebut ditarik suatu kesimpulan untuk menilai kinerja keuangannya.

\subsection{Sumber dan Jenis Data}

Sedangkan sumber data pada penelitian ini ada dua, yaitu:

1. Data umum, yaitu data yang berwujud deskripsi atau penjelasan-penjelasan. Dalam hal ini meliputi pengambilan data mengenai sejarah singkat PT Bakrie Sumatera Plantations,Tbk.dan PT. Astra Agro Lestari, Tbk.

2. Data Khusus, yaitu data yang telah disusun oleh perusahaan sedangkan peneliti hanya mengambil data untuk bahan penulisan tugas akhir. Dalam hal ini adalah laporan keuangan PT Bakrie Sumatera Plantations, Tbk. dan PT. Astra Agro Lestari, Tbk. Periode 2014-2016.

\subsection{Metode Pengumpulan Data}

Metode pengumpulan data sekunder sering disebut metode pengumpulan bahan dokumen atau dokumentasi. yaitu data yang dikumpulkan dari PT. Bakrie Sumatera Plantations, Tbk. dan PT. Astra Agro Lestari, Tbk. yaitu profil dan laporan keuangan periode 2014-2016. 


\subsection{Metode Analisis Data}

Penelitian ini menggunakan analisis deskriftif, yaitu suatu analisis yang berupaya mendeskripsikan secara sistematis, faktual dan aktual mengenai fakta untuk menarik kesimpulan yang logis mengenai data-data hasil penelitian yang akan dianalisis, yaitu analisis rasio-rasio keuangan.

\section{Pembahas an}

\subsection{Rasio Likuiditas}

Rasio mampu menggambarkan kemampuan perusahaan dalam memenuhi kewajiban (utang) jangka pendek. Untuk mencari rasio ini digunakan alat ukur yaitu melalui Rasio Lancar (Rasio Lancar).

Rasio Lancar (Rasio Lancar) diukur dengan membandingkan aktiva lancar dengan utang lancar/kewajiban lancar, sehingga Rasio Lancar pada PT. Bakrie Sumatera Plantations, Tbk. dan PT. Astra Agro Lestari, Tbk. didapat sebagai berikut:

$$
\text { Rasio Lancar }=\frac{\text { Aktiva Lancar }}{\text { Utang Lancar }}
$$

Tabe1 3.1.Hasil Perhitungan Rasio Lancar PT. Bakrie Sumatera Plantations, Tbk. Periode 2014- 2016. (dalam ribuan rupiah)

Tabel 3.1. analisis biaya produksi kebun getas tahun 2015 terhadap anggaran

\begin{tabular}{|c|c|c|c|}
\hline No. Rek & 2014 & 2015 & 2016 \\
\hline $\begin{array}{l}\text { Aktiva } \\
\text { Lancar }\end{array}$ & $\begin{array}{r}2,597,49 \\
6,750\end{array}$ & $1,473,246,391$ & $1,014,926,396$ \\
\hline $\begin{array}{l}\text { Utang } \\
\text { Lancar }\end{array}$ & $\begin{array}{r}7,713,22 \\
1,911\end{array}$ & $8,016,907,027$ & $10,292,576,380$ \\
\hline $\begin{array}{l}\text { Rasio } \\
\text { Lancar }\end{array}$ & 0.34 & 0.18 & 0.10 \\
\hline $\begin{array}{l}\text { Analisis } \\
\text { Rasio }\end{array}$ & $\begin{array}{l}\text { setiap Rp } \\
1 \text { utang } \\
\text { lancar } \\
\text { dijamin } \\
\text { Rp } 0.34 \\
\text { aktiva } \\
\text { lancar }\end{array}$ & $\begin{array}{l}\text { setiap } \mathrm{Rp} \quad 1 \\
\text { utang } \\
\text { lancar dijamin } \\
\text { oleh Rp } 0.18 \\
\text { aktiva lancar }\end{array}$ & $\begin{array}{l}\text { setiap Rp } 1 \text { utang } \\
\text { lancar dijamin } \\
\text { oleh Rp } 0.10 \\
\text { aktiva lancar }\end{array}$ \\
\hline
\end{tabular}

Su m ber : RKAP dan LM Ke bu netas tahun 2015
Tabel 3.2.Hasil Perhitungan Rasio Lancar PT. Astra Agro Lestari, Tbk.

Periode 2014- 2016. (dalam jutaan rupiah)

\begin{tabular}{|c|c|c|c|}
\hline No. Rek & 2014 & 2015 & 2016 \\
\hline $\begin{array}{l}\text { Aktiva } \\
\text { Lancar }\end{array}$ & $2,403,615$ & $2,814,123$ & $4,051,544$ \\
\hline $\begin{array}{l}\text { Utang } \\
\text { Lancar }\end{array}$ & $4,110,955$ & $3,522,133$ & $3,942,967$ \\
\hline $\begin{array}{l}\text { Rasio } \\
\text { Lancar }\end{array}$ & 0.58 & $\mathbf{0 . 8 0}$ & 1.03 \\
\hline $\begin{array}{l}\text { Analisis } \\
\text { Rasio }\end{array}$ & $\begin{array}{l}\text { setiap Rp } 1 \\
\text { utang } \\
\text { lancar dijamin } \\
\text { oleh Rp } 0.58 \\
\text { aktiva lancar }\end{array}$ & $\begin{array}{l}\text { setiap Rp 1 } \\
\text { utang } \\
\text { lancar } \\
\text { dijamin } \\
\text { oleh Rp } \\
0.80 \text { aktiva } \\
\text { lancar }\end{array}$ & 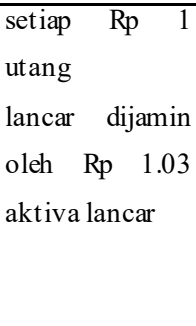 \\
\hline
\end{tabular}

Berdasarkan data tabel 3.1 dapat dilihat bahwa pada tahun 2014 Rasio Lancar PT. Bakrie Sumatera Plantations,Tbk. adalah 0.34 kali. Pada tahun 2015 mengalami penurunan 0.16 kali dari 0.34 kali menjadi 0.18 kali atau menurun 47.51\%. Pada tahun 2016 kembali menurun 0.08 kali dari 0.18 kali menjadi 0.10 kali atau menurun $43.53 \%$.

Data tabel 3.2 bahwa pada tahun 2014 adalah 0.58 kali. Pada tahun 2015 mengalami kenaikan 0.22 kali dari 0.58 kali menjadi 0.80 kali atau naik $37.63 \%$. Pada tahun 2016 kembali naik 0.23 kali dari 0.80 kali menjadi 1.03 kali atau naik 28,79\%.

Rasio Lancar pada PT. Astra Agro Lestari, Tbk. mengalami peningkatan dari 2014-2016. Ini berarti, bahwa setiap tahunnya jumlah persediaan meningkat dan penjualan juga meningkat yang menyebabkan rasio lancar setiap tahun mengalami peningkatan, sehingga perusahaan lebih mampu membayar atau melunasi kewajiban keuangan jangka pendeknya. Jadi jika dinilai dari Likuiditasnya kinerja keuangan PT. Astra Agro Lestari, Tbk. periode 2014-2016 dalam kondisi baik.

\subsection{Rasio Aktivitas}

Rasio aktivitas (Activity Ratio) digunakan untuk mengukur efektivitas perusahaan dalam menggunakan aktiva yang dimilikinya. Untuk mengukur rasio ini 
digunakan Rasio Perputaran Total Aktiva (Total Assets Turnover Ratio).

Rasio Perputaran Total Aktiva (Total Assets Turnover Ratio) merupakan rasio yang digunakan untuk mengukur berapa lama penagihan piutang selama satu periode atau berapa kali dana yang ditanamakan dalam dalam piutang ini berputar dalam satu periode. Untuk mengukurnya dapat digunakan rumus dibawah ini:

Rasio PerputaranTotal Aktiva $=\frac{\text { Penjualan }}{\text { Total Aktiva }}$

Tabel 3.3.Hasil Perhitungan Rasio Perputaran

Total Aktiva PT. Bakrie Sumatera Plantations,

Tbk. Periode 2014-2016. (dalam ribuan rupiah)

\begin{tabular}{|c|c|c|c|}
\hline & 2014 & 2015 & 2016 \\
\hline Penjualan & $2,636,703,408$ & $\begin{array}{r}2,021,6 \\
46,748\end{array}$ & $1,565,243,696$ \\
\hline $\begin{array}{l}\text { Total Aset } \\
\text { Lancar }\end{array}$ & $2,597,496,750$ & $\begin{array}{l}1,473,2 \\
46,391\end{array}$ & $1,014,926,396$ \\
\hline $\begin{array}{l}\text { Total Aset } \\
\text { T. Lancar }\end{array}$ & $12,926,935,207$ & $\begin{array}{r}13,834 \\
775,68 \\
1\end{array}$ & $13,685,391,964$ \\
\hline Total Aset & $15,524,431,957$ & $\begin{array}{r}15,308 \\
022,07 \\
2\end{array}$ & $14,700,318,360$ \\
\hline TAT & 0.17 & 0.13 & 0.11 \\
\hline $\begin{array}{l}\text { Analisis } \\
\text { Rasio }\end{array}$ & $\begin{array}{l}\text { Setiap } \quad \text { Rp } \quad 1 \\
\text { aktiva mampu } \\
\text { menghasilkan } \\
\text { penjualan Rp } \\
0.17\end{array}$ & $\begin{array}{l}\text { Setiap } \\
\text { Rp } 1 \\
\text { aktiva } \\
\text { mampu } \\
\text { mengh } \\
\text { asilkan } \\
\text { penjual } \\
\text { an Rp } \\
0.13\end{array}$ & $\begin{array}{l}\text { Setiap Rp } 1 \\
\text { aktiva mampu } \\
\text { menghasilkan } \\
\text { penjualan Rp } \\
0.11\end{array}$ \\
\hline
\end{tabular}

Tabel 3.4.Hasil Perhitungan Rasio Total Perputaran Aktiva PT. Astra Agro Lestari, Tbk. Periode 2014- 2016. (dalam jutaan rupiah)

\begin{tabular}{|l|l|r|l|}
\hline & 2014 & 2015 & 2016 \\
\hline Penjualan & $16,305,831$ & $\begin{array}{r}13,059, \\
216\end{array}$ & $14,121,374$ \\
\hline $\begin{array}{l}\text { Total Aset } \\
\text { Lancar }\end{array}$ & $2,403,615$ & $\begin{array}{r}2,814,1 \\
23\end{array}$ & $4,051,544$ \\
\hline Total Aset & $16,155,739$ & 18,698, & $20,174,578$ \\
\hline
\end{tabular}

\begin{tabular}{|c|c|c|c|}
\hline T. Lancar & & 248 & \\
\hline $\begin{array}{l}\text { Total } \\
\text { Aktiva }\end{array}$ & $18,559,354$ & $\begin{array}{r}21,512 \\
371\end{array}$ & $24,226,122$ \\
\hline TAT & 0.88 & 0.61 & 0.58 \\
\hline $\begin{array}{l}\text { Analisis } \\
\text { Rasio }\end{array}$ & $\begin{array}{l}\text { Setiap } \mathrm{Rp} \quad 1 \\
\text { aktiva mampu } \\
\text { menghasilkan } \\
\text { penjualan } \mathrm{Rp} \\
0.88\end{array}$ & $\begin{array}{l}\text { Setiap } \\
\text { Rp 1 } \\
\text { aktiva } \\
\text { mampu } \\
\text { mengh } \\
\text { asilkan } \\
\text { penjual } \\
\text { an Rp } \\
0.61\end{array}$ & $\begin{array}{l}\text { Setiap } \mathrm{Rp} \quad 1 \\
\text { aktiva mampu } \\
\text { menghasilkan } \\
\text { penjualan Rp } \\
0.58\end{array}$ \\
\hline
\end{tabular}

Berdasarkan data table 3.3 dapat dilihat Total Assets Turnover Ratio PT. Bakrie Sumatera Plantations, Tbk. pada tahun 2014 adalah 0.17 kali. Pada tahun 2015 menurun sebesar 0.04 kali dari 0.17 kali menjadi 0.13 kali. Pada tahun 2016 menurun kembali 0.02 kali dari 0.13 kali menjadi 0.11 kali.

Tabel 3.4, pada tahun 2014 adalah 0.88 kali. Pada tahun 2015 menurun sebesar 0.21 kali dari 0.88 kali menjadi 0.61. Pada tahun 2016 menurun kembali 0.03 kali dari 0.61 kali men jadi 0.58 kali. Hal ini disebabkan karena terjadi kenaikan total aktiva tahun 2015 yaitu 15.91\% atau Rp.2.953.017,- dan pada tahu 2016 kenaikan sebesar 12.61\% atau Rp.2.713.751,-. Namun penjualan 2015 dan 2016 mengalami penurunan yaitu sebesar $19.91 \%$ dan $8.13 \%$ atau Rp.3.246.615,- dan Rp. 1.062.158,-.

Jika dinilai dari pertumbuhan Rasio Perputaran Total Aktiva periode 2014-2016, kedua perusahaan kurang baik mengelola aktiva yang dimilikinya karena dapat dilihat bahwa kemampuan total aktiva dalam menghasilkan penjualan kurang memaksimalkan dalam menggunakan aktivanya untuk memperoleh keuntungan.

\subsection{Rasio Solvabilitas}

Solvabilitas (Solvability) adalah kemampuan perusahaan membayar utang-utang dalam jangka panjang. Untuk mengukurnya dapat digunakan Rasio Utang.

Rasio Utang merupakan rasio yang digunakan untuk mengukur perbandingan antara 
total utang dengan total aktiva. Untuk melakukan pencarian dapat digunakan rumus di bawah ini:

$$
\text { Rasio Utang }=\frac{\text { Total Utang }}{\text { Total Aset }}
$$

Tabel 3.5.Hasil Perhitungan Rasio Utang PT Bakrie Sumatera Plantations, Tbk. Periode

2014- 2016. (dalam ribuan rupiah)

\begin{tabular}{|l|c|c|c|}
\hline $\begin{array}{l}\text { Utang } \\
\text { Jkende } \\
\text { k }\end{array}$ & $\mathbf{2 0 1 4}$ & $\mathbf{2 0 1 5}$ & $\mathbf{2 0 1 6}$ \\
\hline $\begin{array}{l}\text { Utang } \\
\text { Jk } \\
\text { Panjan } \\
\text { g }\end{array}$ & $\mathbf{7 , 7 1 3 , 2 2 1 , 9 1 1}$ & $\mathbf{8 , 0 1 6 , 9 0 7 , 0 2 7}$ & $\mathbf{1 0 , 2 9 2 , 5 7 6 , 3 8 0}$ \\
\hline $\begin{array}{l}\text { Total } \\
\text { Kewaji } \\
\text { ban }\end{array}$ & $\mathbf{5 , 6 5 1 , 4 7 4 , 2 3 0}$ & $\mathbf{5 , 6 2 3 , 1 7 8 , 5 6 2}$ & $\mathbf{3 , 2 1 0 , 0 5 2 , 7 9 8}$ \\
\hline $\begin{array}{l}\text { Total } \\
\text { Aset }\end{array}$ & $\mathbf{1 3 , 3 6 4 , 6 9 6 , 1 4 1}$ & $\mathbf{1 3 , 6 4 0 , 0 8 5 , 5 8 9}$ & $\mathbf{1 3 , 5 0 2 , 6 2 9 , 1 7 8}$ \\
\hline $\begin{array}{l}\text { Rasio } \\
\text { Utang }\end{array}$ & $\mathbf{2 , 5 9 7 , 4 9 6 , 7 5 0}$ & $\mathbf{1 , 4 7 3 , 2 4 6 , 3 9 1}$ & $\mathbf{1 , 0 1 4 , 9 2 6 , 3 9 6}$ \\
\hline $\begin{array}{l}\text { Analisi } \\
\text { s Rasio }\end{array}$ & $\begin{array}{l}\text { 86\% dari total } \\
\text { aktiva dibiayai } \\
\text { berasal } \\
\text { dari }\end{array}$ & $\begin{array}{l}\text { 89\% dari total } \\
\text { aktiva dibiayai } \\
\text { berasal } \\
\text { utang }\end{array}$ & $\begin{array}{l}\text { dari } \\
\text { aktiva dibiayai } \\
\text { berasal } \\
\text { utang }\end{array}$ \\
\hline & & $\mathbf{8 a r i}$ \\
\hline
\end{tabular}

Tabel 3.6.Hasil Perhitungan Rasio Utang PT. Astra Agro Lestari, Tbk.

Periode 2014- 2016. (dalam jutaan rupiah)

\begin{tabular}{|c|c|c|c|}
\hline & 2014 & 2015 & 2016 \\
\hline $\begin{array}{ll}\text { Utang } & \text { Jk } \\
\text { Pendek } & \end{array}$ & $4,110,955$ & $3,522,133$ & $3,942,967$ \\
\hline $\begin{array}{ll}\text { Utang } & \text { Jk } \\
\text { Panjang } & \end{array}$ & $2,614,621$ & $6,291,451$ & $2,689,673$ \\
\hline $\begin{array}{l}\text { Total } \\
\text { Kewajiban }\end{array}$ & Rp. 6,725,576 & $\begin{array}{r}\text { Rp. } \\
9,813,584\end{array}$ & $6,632,640$ \\
\hline Total Aset & Rp. 2,403,615 & $\begin{array}{r}\text { Rp. } \\
2,814,123\end{array}$ & $4,051,544$ \\
\hline Rasio Utang & $36 \%$ & $46 \%$ & $27 \%$ \\
\hline Analisis Rasio & $\begin{array}{l}36 \% \text { dari total } \\
\text { aktiva dibiayai } \\
\text { berasal dari } \\
\text { utang }\end{array}$ & $\begin{array}{l}46 \% \text { dari } \\
\text { total } \\
\text { aktiva } \\
\text { dibiayai } \\
\text { berasal dari }\end{array}$ & $\begin{array}{l}27 \% \text { dari } \\
\text { total } \\
\text { aktiva } \\
\text { dibiayai } \\
\text { berasal }\end{array}$ \\
\hline
\end{tabular}

\begin{tabular}{|l|l|l|l|}
\hline & & utang & dari utang \\
\hline
\end{tabular}

jika dinilai dari pertumbuhan Rasio Utang periode 2014-2016 terjadi perubahan yang signifikan yang setiap tahunnya mengalami kenaikan. Jika din ilai dari Manajemen Utangnya kinerja keuangan PT. Bakrie Sumatera Plantations, Tbk. kurang baik karena lebih dari 50\% Aktiva yang dimiliki perusahaan bersumber dari hutang.

Sedangkan PT. Astra Agro Lestari, Tbk. berdasarkan data tabel 5.6 dapat dilihat bahwa Rasio Utang pada tahun 2014 adalah 36\%. Pada tahun 2015 meningkat $10 \%$ dari $36 \%$ menjadi $46 \%$. Pada tahun 2016 menurun $19 \%$ dari $46 \%$ menjadi $27 \%$

Apabila Rasio Utang PT. Astra Agro Lestari, Tbk. yang digunakan tinggi, maka semakin sulit bagi perusahaan untuk memperoleh tambahan pinjaman karena dikhawatirkan perusahaan tidak mampu membayar utang-utangnya dengan aktiva yang dimilkinya karena sebagian besar perusahaan dibiayai oleh utang. Begitupun sebaliknya apabila rasionya semakin rendah, maka semakin kecil perusahaan dibiayai oleh utang dan hal itu akan lebih baik untuk Perusahaan. Rasio Utang pada tahun 2016 lebih baik dibandingkan dengan tahun - tahun sebelumnya karena persentase aktiva yang dibiayai oleh utang lebih sedikit dibandingkan tahun yang lainnya.

\subsection{Rasio Profitabilitas}

Rasio Profitabilitas (Profitability Ratio) merupakan rasio untuk menilai kemampuan perusahaan dalam mencari keuntungan. Untuk mengkurnya dapat digunakan rumus sebagaiberikut :

$$
\text { Rasio ROI }=\frac{\text { Laba Bersih }}{\text { Total Aset }}
$$

Tabel 3.7.Hasil Perhitungan ROA Ratio PT. Bakrie Sumatera Plantations, Tbk.

Periode 2014- 2016. (dalam ribuan rupiah)

\begin{tabular}{|l|r|r|r|}
\hline & \multicolumn{1}{|c|}{2014} & \multicolumn{1}{|c|}{2015} & \multicolumn{1}{|c|}{2016} \\
\hline EAT & $(682,944$, & $\mathbf{( 4 6 9 , 8 5 6 , 6 9 9 )}$ & $(484,668,62$ \\
& $\mathbf{0 0 2})$ & & $9)$ \\
\hline Total Aktiva & $\mathbf{1 5 , 5 2 4 , 4}$ & $\mathbf{1 5 , 3 0 8 , 0 2 2 , 0 7 2}$ & $\mathbf{1 4 , 7 0 0 , 3 1 8 ,}$ \\
& 31,957 & & $\mathbf{3 6 0}$ \\
\hline ROA & $-4 \%$ & $-3 \%$ & $-3 \%$ \\
\hline
\end{tabular}




\begin{tabular}{|l|l|lr|l|}
\hline Analisis Rasio & Setiap Rp & Setiap Rp 1 & Setiap Rp 1 \\
& 1 Aktiva & Aktiva yang & Akt iva \\
& yang & dimiliki, belum & yang \\
& dimiliki, & mampu & dimiliki, \\
& belum & berkontribusi & belum \\
mampu & untuk EAT & mampu \\
& berkontri & & berkontribu \\
& busi & & si untuk \\
& untuk & & EAT \\
& EAT & & & \\
\hline
\end{tabular}

Tabel 3.8.Hasil Perhitungan ROA Ratio PT. Astra Agro Lestari, Tbk.

Periode 2014- 2016. (dalam jutaan rupiah)

\begin{tabular}{|c|c|c|c|}
\hline & 2014 & 2015 & 2016 \\
\hline EAT & $2,622,072$ & 695,684 & $2,114,299$ \\
\hline $\begin{array}{l}\text { Total } \\
\text { Aktiva }\end{array}$ & $18,559,354$ & $21,512,371$ & $24,226,122$ \\
\hline ROA & $14 \%$ & $3 \%$ & $9 \%$ \\
\hline $\begin{array}{l}\text { Analisis } \\
\text { Rasio }\end{array}$ & $\begin{array}{l}\text { Setiap Rp 1 } \\
\text { Aktiva yang } \\
\text { dimiliki, } \\
\text { mampu } \\
\text { menghasilkan } \\
\text { EAT sebesar } \\
14 \%(0.14)\end{array}$ & $\begin{array}{l}\text { Setiap Rp } 1 \\
\text { Aktiva yang } \\
\text { dimiliki, } \\
\text { mampu } \\
\text { menghasilkan } \\
\text { EAT sebesar } \\
3 \%(0.3)\end{array}$ & $\begin{array}{l}\text { Setiap Rp } 1 \\
\text { Aktiva yang } \\
\text { dimiliki, } \\
\text { mampu } \\
\text { menghasilkan } \\
\text { EAT sebesar } \\
9 \%(0.9)\end{array}$ \\
\hline
\end{tabular}

Berdasarkan data tabel 3.7 dapat dilihat bahwa PT. Bakrie Sumatera Plantation, Tbk pada tahun 2014-2016 mengalami rugi dan perusahaan belum mampu berkontribusi untuk laba bersih setelah pajak dengan as et yang dimiliki.

Return on Assets pada PT. Astra Agro Lestari, Tbk. pada tahun 2014 adalah 14\% pada tabel 5.8. Pada tahun 2015 menurun 11\% dari 14\% menjadi 3\%. Pada tahun 2016 naik 6\% dari 3\% menjadi 9\%.

Semakin rendah Return on Invesment maka akan semakin kurang baik dampaknya terhadap perusahaan dan begitu sebaliknya. Return on Invesment pada tahun 2014 lebih baik dibanding tahun 2015 dan 2016, karena persentase peningkatan penghasilan aktiva menunjukan produktivitas dari perusahaan menghasilkan persentase laba yang tinggi.
3.5 Pengaruh Biaya Produksi Terhadap Laba Perusahaan pada PT Perkebunan Nusantara IX Kebun Getas

Setiap perusahaan mempunyai tujuan untuk mencapai target yang telah ditetapkan, baik berupa menghasilkan laba, kelangsungan hidup (goal congruence), pertumbuhan perusahaan, menciptakan kesejahteraan karyawan maupun kesejahteraan anggota masyarakat.

Berikut ini merupakan perhitungan laba rugi kebun getas pada tahun 2015 dan tahun 2016 :

Tabel 3.9 Laba Rugi Kebun Getas Pada Tahun 2015

\begin{tabular}{|lr|r|r|}
\hline \multicolumn{1}{|l|}{ URAIAN } & \multicolumn{1}{|c|}{ TO TAL } & \multicolumn{1}{|c|}{ (\%) } \\
\hline Pendapatan & 40.690 .863 .214 & $100 \%$ \\
\hline HPP & 38.695 .301 .635 & $95 \%$ \\
\hline & Laba & $\mathbf{1 . 9 9 5 . 5 6 1 . 5 8 0}$ & $\mathbf{5 \%}$ \\
& Kotor & & \\
\hline Beban Usaha & & 10.189 .220 .140 & $25 \%$ \\
\hline & Laba & $\mathbf{( 8 . 1 9 3 . 6 5 8 . 5 6 0 )}$ & $\mathbf{- 2 0 \%}$ \\
& Usaha & & \\
\hline
\end{tabular}

Pada tabel 3.9 pada tahun 2015, Kebun Getas memiliki pendapatan sebesar Rp. 40.690.863.214, dan mengeluarkan biaya produksi sebesar Rp. 22.441.033.777. Dengan biaya produksi sebesar Rp. 22.441.033.777, Kebun Getas mengalami kerugian sebesar Rp. 8.193.658.560.

Tabel 3.10 laba rugi kebun getas pada tahun 2016

\begin{tabular}{|l|r|r|}
\hline URAIAN & \multicolumn{1}{|l|}{ TOTAL } & (\%) \\
\hline Pendapatan & 66.906 .992 .598 & $100 \%$ \\
\hline Hpp & 54.770 .764 .992 & $82 \%$ \\
\hline Laba Kotor & $\mathbf{1 2 . 1 3 6 . 2 2 7 . 6 0 6}$ & $\mathbf{1 8 \%}$ \\
\hline Beban Usaha & 10.264 .917 .281 & $15 \%$ \\
\hline Laba Usaha & $\mathbf{1 . 8 7 1 . 3 1 0 . 3 2 5}$ & $\mathbf{3 \%}$ \\
\hline
\end{tabular}

Pada tahun 2016, Kebun Getas memiliki pendapatan sebesar Rp. 66.906.992.598, dan mengeluarkan biaya produksi sebesar Rp. 24.879.085.992. Dengan biaya produksi sebesar Rp. 24.879.085.992, Kebun Getas mengalami keuntungan atau laba sebesar Rp. 1.871.310.325. Seperti yang tertera pada tabel 5.6

Biaya produksi berpengaruh pada laba yang diperoleh perusahaan. Selain itu, laba perusahaan juga berhubungan pada HPP dan Beban Usaha. Pada tahun 
2015, kebun getas mengeluarkan biaya produksi sebesar Rp. 22.441.033.777 yang menyebabkan HPP kebun getas pada tahun 2015 sebesar Rp. 38.695.301.635. Namun, beban usaha yang dikeluarkan kebun getas pada tahun 2015 sebesar Rp. 10.189.220.140. Yang menyebabkan kebun getas mengalami kerugian sebesar Rp. 8.193.658.560.

Sedangkan pada tahun 2016, kebun Getas mengeluarkan biaya produksi sebesar Rp. 24.879.085.992 yang menyebabkan HPP kebun getas pada tahun 2016 sebesar Rp. 54.770.764.992. Dan beban usaha yang dikeluarkan kebun getas pada tahun 2016 sebesar Rp. 10.264.917.281. Yang menyebabkan kebun getas memperoleh laba sebesar Rp. 1.871 .310 .325 .

\subsection{Rekapitulasi Analisis Rasio}

Tabel 3.11 Tabel Hasil Analisis Rasio pada PT.

Bakrie Sumatera Plantations, Tbk. dan PT. Astra

Agro Lestari, Tbk. Periode 2014-2016

\begin{tabular}{|l|r|c|c|c|c|c|}
\hline \multirow{2}{*}{$\begin{array}{l}\text { Ketera } \\
\text { ngan }\end{array}$} & \multicolumn{2}{|c|}{$\begin{array}{r}\text { PT. Bakrie Sumatera } \\
\text { Plantations, Tbk. }\end{array}$} & \multicolumn{3}{|c|}{$\begin{array}{r}\text { PT. Astra Agro Lestari, } \\
\text { Tbk. }\end{array}$} \\
\cline { 2 - 7 } & 2014 & 2015 & 2016 & 2014 & 2015 & 2016 \\
\hline $\begin{array}{l}\text { Rasio } \\
\text { Lancar }\end{array}$ & 0.34 & 0.18 & 0.10 & 0.58 & 0.80 & 1.03 \\
\hline $\begin{array}{l}\text { TAT } \\
\text { Ratio }\end{array}$ & 0.17 & 0.13 & 0.11 & & & 0.58 \\
\hline $\begin{array}{l}\text { Rasio } \\
\text { Utang }\end{array}$ & $86 \%$ & $89 \%$ & $92 \%$ & & & \\
\hline $\begin{array}{l}\text { ROA } \\
\text { Ratio }\end{array}$ & $-4 \%$ & $-3 \%$ & $-3 \%$ & $14 \%$ & $3 \%$ & $9 \%$ \\
\hline
\end{tabular}

Berdasarkan tabel 3.11 dapat dilihat bahwa kinerja PT. Bakrie Sumatera Plantations, Tbk. dalam kondisi kurang baik, dilihat dari Rasio lancarnya kondisi perusahaan kurang baik karena rasio lancar perusahaan setiap tahun mengalami penurunan yang cukup signifikan. Hal ini disebabkan karena banyaknya hutang jangka panjang yang akan jatuh tempo setiap tahunnya. TAT Ratio juga mengalami penurun setiap tahunnya hal ini disebabkan kurang memaksimalkan penggunaan aktiva sehingga penjualan menurun pada periode tersebut. Dilihat dari Rasio Utang, bahwa lebih dari 50\% aktiva yang dimiliki berasal dari hutang. ROA Ratio pada periode tersebut aktiva perusahaan belum mampu menghasilkan laba bersih setelah pajak.

\section{Kesimpulan}

1. Setiap tahunnya jumlah persediaan meningkat dan penjualan juga meningkat yang menyebabkan rasio lancar setiap tahun mengalami peningkatan, sehingga perusahaan lebih mampu membayar atau melunasi kewajiban keuangan jangka pendeknya. Jadi jika dinilai dari Likuiditasnya kinerja keuangan PT. Astra Agro Lestari,Tbk periode 2014-2016 dalam kondisi baik.

2. Rasio Perputaran Total Aktiva periode2014 2016, kedua perusahaan kurang baik mengelola aktiva yang dimilikinya karena dapat dilihat bahwa kemampuan total aktiva dalam menghasilkan penjualan kurang memaksimalkan dalam menggunakan aktivanya untuk memperoleh keuntungan.

3. Jika dinilai dari Manajemen Utangnya kinerja keuangan PT. Astra Agro Lestari, Tbk. baik karena kurang dari 50\% Aktiva yang dimiliki perusahaan bersumber dari hutang.

4. Penurunan Return on Invesment Ratio dikarenakan dikarenakan perusahaan banyak berinvestasi di Aktiva Lancar padahal Aktiva Lancar merupakan Aktiva yang tidak Produktif. Selain itu, banyaknya aktiva yang dimiliki perusahaan yang bersumber dari utang sedangkan kemampuan membayar bunga dan melunasi utang yang akan jatuh tempo mengalami penurunan dan perusahaan juga belum memaksimalkan penggunaan aktiva yang dimilikinya persediaan barang jadi banyak menumpuk di gudang.

\section{Daftar Pustaka}

Annual Report PT. Bakrie Sumatera Plantations, Tbk, tahun 2014, 2015, dan 2016. 
Annual Report PT. Astra Agro Lestari, Tbk, tahun 2014, 2015, dan 2016.

Djumingan. 2006. Analisis Laporan Keuangan. Jakarta: Bumi Aksara.

Hanafi, Mamduh M. dan Abdul Halim. 2016. Analisis Laporan Keuangan. Edisi Ke-5. Yogyakarta : UPP STIM YKPN.

Harahap, Sofyan Syafri. 2008. Analisis Kritis atas Laporan Keuangan. Edisi Ke-1. Jakarta : PT. Raja Grafindo Persada

Ikatan A kuntan Indonesia. 2009. Pernyataan Standar Akuntansi Keuangan No. 1. Revisi 2009. Jakarta : Dewan Standar Akuntansi Keuangan Ikatan Akuntan Indonesia.

Kasmir. 2012 Analisis Laporan Keuangan. Edisi Ke 1-5. Jakarta : Rajawali Pers.

Munawir, S. 2007. Analisa Laporan Keuangan. Edisi Ke-4. Yogyakarta : Liberty.

Prastowo, Dwi. 2011. Analisis Laporan Keuangan.Yogyakarta: UPP STIM YKPN

Rahardjo, Budi. 2007. Keuangan dan Akuntansi, Edisi 1. Cetakan Pertama. Yogyakarta : Graha Ilmu. 